\title{
Differential Expression of Vimentin and GFAP Protein during Brain Development of Mouse Fetuses after Treated with 2-Methoxyethanol
}

\author{
Yulia Irnidayanti ${ }^{1}$, Win Darmanto ${ }^{2}$, Agus Abadi $^{3}$, Yukio Hattori $^{4}$ \& \\ Yasuhiro Yamashiro ${ }^{4}$ \\ ${ }^{1}$ Biology Department, UNJ, Faculty of Mathematics and Science, \\ Jalan Pemuda No. 10, Jakarta 13150, Indonesia \\ ${ }^{2}$ Biology Departement Faculty of Mathematics and Science, Airlangga University, \\ Mulyorejo Kampus C Surabaya 60115, Indonesia \\ ${ }^{3}$ Faculty of Medicine, Airlangga University, \\ Jalan Mayjen Prof. Dr. Moestopo 47, Surabaya, Indonesia 60131 \\ ${ }^{4}$ Division of Clinical Laboratory Science, Faculty of Health Sciences, Yamaguchi \\ University School of Medicine, 1-1-1 Minami-Kogushi, Ube, \\ Yamaguchi 755-8505, Japan \\ Email: irnidayanti@unj.ac.id
}

\begin{abstract}
. 2-methoxyethanol is known as a chemical pollutant that is teratogenic or embryotoxic in animals and humans. 2-ME and its metabolites can damage cells and tissues in the body. Investigation of protein expression due to 2-ME was performed using primary antibodies Vimentin and GFAP. The amount of protein expressed was measured by immunodot blot and densitometry techniques. The results show that the average total change in Vimentin protein levels was higher (22.24\% at gestation day 17 and 18) than in GFAP protein levels $(15.10 \%$ on gestation day 12$)$ in the treatment group. The 2-ME disrupted translation of Vimentin and increased the level of GFAP expression due to the cellular response to toxic materials. It can be concluded that the Vimentin protein is essential for the development of the brain, especially to stimulate cell proliferation for cell repair
\end{abstract}

Keywords: brain; cell repair; disruption; GFAP; proliferation; protein translation; cell response; 2-Methoxyethanol; Vimentin.

\section{Introduction}

The objective of this research was to determine the level of Vimentin absorption and GFAP expression during the development of the fetal mouse brain after treatment with $7.5 \mathrm{mmol} / \mathrm{kg}$ body weight 2-Methoxyethanol (2-ME), injected intra-peritoneally on gestation day 10 (GD 10). The compound of 2methoxyethanol (2-ME) or ethyleneglycol monomethyl ether is one of the glycol ether compounds derived from the compounds of phthalate esters. This compound is widely used as the basic material for plastics. Plastics are

Copyright @ 2012 Published by LPPM ITB, ISSN: 1978-3043, DOI: 10.5614/itbj.sci.2012.44.4.5 
generally used in a variety of everyday human activities, involving products such as household appliances, packing materials, bottles, food containers, toys, water pipes and even for health purposes, such as blood storage for transfusion.

Previous research has reported that some people have been poisoned with 2-ME through penetration into the skin and bronchial tube [1]. Approximately 100,000 people are poisoned by 2-ME each year, and, predictably women who are still fertile or able to produce offspring [2]. Teratogenic effects of 2-ME is caused by the metabolism of 2-ME in the liver cells into 2-metoksiasetaldehid, which is catalyzed by the enzyme of alcohol dehydrogenase.2-metoksiasetaldehid will be oxidized with enzyme of aldehyde dehydrogenase into metoksiasetat acid (MAA). MAA is a major metabolite of 2-ME, are known to be embryotoxic and teratogenic [3,4].

2-Methoxyethanol is known as a toxic or also teratogenic in several species of mammals [5]. This compound is also known as a chemical that can potentially cause abnormalities such as excencephaly in mouse fetuses [6]. The results of Prihiyantoro [7] show that fetal mice whose dams were given 2-ME contracted excencephaly, thinning of the cerebral cortex, and cerebellum foliasi pattern abnormalities. There was also a decrease in total protein levels in the brains of the treatment group, which was given a dose of $2-\mathrm{ME} 12.5 \mathrm{mmol} / \mathrm{kg}$ body weight on GD 11.

The brain is a very important organ as a coordinator of all systems in the body. Therefore, a failure in the development of the brain will result in a disruption of almost every function of the body. This is because the formation of the brain occurs at an early stage of embryonic development, but the process is completed only at a late stage, or even after birth. The development of the brain involves processes such as cell proliferation, cell migration, cell interactions, cell adhesion, cell differentiation and morphogenesis [8]. All mechanisms also involve the formation of extracellular matrix proteins. In the central nervous system, the extracellular protein substances are composed of proteins that are secreted by extracellular cells, especially astroglial cells. Extracellular protein substances, which is embedded in between the cells, serve as the substance of the extracellular matrix.

During the embryonic period, the brain expresses a variety of extracellular proteins. Vimentin and GFAP are extracellular proteins that are secreted by astroglial cells, act as a substrate for the cells to migrate and as cell signaling response in brain development [9]. The pattern of protein expression depends on tissue differentiation and is temporarily. Disruption of the extracellular proteins of the brain can cause impairment of the cell interaction mechanisms, which ultimately may disrupt the brain development process. Additionally, 
interference of protein synthesis in the astroglial cells will also inhibit migration and the neuroblast proliferation process, and can cause developmental abnormalities in the brain.

It has been reported that migration disorders, especially Purkinye cell migration, can cause abnormal cerebellar foliation patterns in mice $[6,10]$. Abnormalities in Purkinye cell migration have also been clearly demonstrated as a result of the decreased expression of extracellular Reelin protein. Reelin is a type of extracellular protein that is secreted by Cajal-Retzius cells, located in the marginal zone of the cerebral cortex of the brain [11]. This protein is thought to function as a regulator of cell positioning, guide the migration of nerve cells in the brain [12]. Apparently, extracellular Reelin is not the only protein that plays a role in the process of brain development. It is well known that brain development involves multiple processes and dynamic changes, for which various proteins are required. Several proteins are known to be involved in brain development, such as Fibronectin, Tenascin, Vimentin, Ncam [13-16].

Previously, we have found the mRNA levels of gene expression of extracellular Fibronectin, Tenascin, Vimentin, Neurofilament and neural cell adhesion molecules (Ncam) on GD 10. Vimentin is expressed very highly compared to the others [17]. These data are supported by the results of previous studies. The brains of embryonic mice on GD 12, whose dams were given 2-ME on GD 10, also showed a very high mRNA level of the Vimentin gene [18]. Therefore, we suspect that extracellular proteins such as Vimentin play an important role in brain development, especially in the process of neurogenesis. At an early stage of central nervous system development, the extracellular matrix of immature astrocytes is mainly composed of Vimentin. This protein was detected as early as GD 11, in radial fibers of the neural tube in the ventricular zone [19]. Then, around birth, a switch from Vimentin to GFAP takes place. Vimentin is expressed as extracellular protein in early development, and is used as a marker of glial cell differentiation. Vimentin plays a role in maintaining the integrity of the structure of the cell, maintaining cell shape and cell stability. Vimentin also plays a role in replication, recombination and repair of DNA [19]. Vimentin disappears and is progressively replaced by GFAP (glial acidic acid protein) in differentiated astroglial cells that transiently coexpress the two proteins. GFAP functions in the formation of the structural framework of the cell and the cell shape, and organizes the organelles in the cytoplasm. A structural role of the protein is as the cytoskeleton, which is responsible not only for movement inside the cell, but also for internal transport and cytoplasmic organelles. GFAP and Vimentin are both components of intermediate filaments of astrocytes cells. Astrocytes are glial cells, appearing in the early development of the brain, and act to guide the growth of nerve cells. 
Based on the above background, this research was conducted to determine the differences in Vimentin and GFAP levels during the period of brain development from GD 11 to GD 18 after administration of 2-Methoxyethanol on GD 10, using immunodot blot and densitometry techniques. Both proteins are related and secreted by the same cells. Vimentin and GFAP are often used as markers in the development of brain tissue.

\section{$2 \quad$ Material and Methods}

\subsection{Experimental Animals, Material and Sample Collection}

For this experiment, female mice, Mus musculus (Swiss Webster), were used, supplied by the Animal House and Toxicology Laboratories, University of Indonesia. Rearing the animals was done in a room at $23-27^{\circ} \mathrm{C}$ with $83 \%$ humidity. Food and water were given ad libitum. Ten- to twelve-week old female mice were mated with a male (1:1) overnight. A vaginal plug that was detected the next morning defined day zero of gestation [20]. 2-ME in liquid form was used, produced by Wako Pure Chemical Industries, Ltd. Japan (product number 135-07762). 2-ME diluted with sterilized distilled water was administered by peritoneal injection at a dose of $7,5 \mathrm{mmol} / \mathrm{kg}$ body weight into the pregnant mice on GD 10. The control mice were injected with the same volume of sterile distilled water.

The pregnant mice were sacrificed by cervical dislocation on GD 11, 12, 13, 14, $15,16,17$, and 18, and then dissected. The uterus containing the embryo was taken and put into a falcon tube containing buffer solution. The uterus was opened, the embryo was taken out and the brains of the fetus were isolated under stereo microscope. Brain samples were put into an Eppendorf tube, and the tubes were stored in a box containing dry ice. Preparation of the fetal brain proteins was carried out using Cell Lysis M reagent solution and suspended using a pellet pestle.

\subsection{Measurement of Protein Concentration}

Measurement of the protein concentration was performed using a BCA Smart Kit, cat. no. 21071 (Japan). This kit consists of solution A, solution B and a solution of $2 \mathrm{mg} / \mathrm{ml} \mathrm{BSA}$. BSA standard solution was prepared for NanoDrop instrument calibration, in order to obtain a straight graph. BSA solution was prepared by adding BSA stock solution with distillated water to produce a series of increasing concentration. In the next step working solution (WS) was prepared by mixing the A solution with the B solution in a ratio of 50:1. 
$5 \mu 1$ of each standard or protein sample replicate was pippeted into a microplate well. Then $100 \mu \mathrm{l}$ of working solution was added to each well and mixed thoroughly. The wells were covered and then incubated at $37^{\circ} \mathrm{C}$ for 30 minutes. Finally, the microplate well sample was cooled at room temperature, and the absorbance level was measured using a NanoDrop 2000 Thermo.

\subsection{Immunodot Blot}

To prepare the samples, a protein concentration with $300 \mu \mathrm{g} / \mu 1$ was made, as well as the membrane to be used for the immunodot blot. A test of the immunodot blot was performed with nitrocellulose membranes that were soaked with protein sample. The membranes were then immersed in 5\% skim milk, incubated at $4^{\circ} \mathrm{C}$ overnight. After wasing with PBST 20x, the membranes were added with primary antibody and then incubated for two hours. After soaking with secondary antibody they were then incubated overnight at room temperature. The membranes were stained with AEC solution and coloured red as a result of the immunodot blot. Densitometry techniques were performed to measure the absorption of color density by Vimentin and GFAP in the membranes, scanned and calculated using Adobe Photoshop.

\subsection{Data Analysis}

The data from the densitometry measurements were tested by t-test at $\alpha 0.05$, by comparing with the control group.

\section{$3 \quad$ Results}

It is known that there are several extracellular genes that are involved in early brain development. Based on a survey of previous studies, the Vimentin gene expression level is considerably higher than the expression level of other genes [17]. This raises the question whether the expression of the Vimentin gene is expressed in proteins and whether it is continuously expressed during brain development or immediately replaced by another protein. These questions were reason to investigate the differences in expression of GFAP and Vimentin through the levels of absorption and expression. Another reason was that both proteins are secreted by the same cells, astrocyte cells.

Normally, Vimentin is expressed during early brain development and is replaced by GFAP at the moment of birth [21]. The respective expressions of these two proteins are closely related, quantitatively and qualitatively. We know that, normally, in the early development of the nervous system, glial and astroglial cells mature, composed by Vimentin [22], and that at the moment of birth, the Vimentin protein will be replaced by GFAP. But we do not know 
when Vimentin proteins are replaced by other proteins, especially GFAP, after treatment with 2-Methoxyethanol.

In this study, a positive control and a negative control were used. The negative control was used to control the work of the immunodot blot. The positive control was used for comparison with the treatment group.. The immunodot blot results were calculated with densitometry techniques by measuring absorption of color density by the Vimentin and GFAP proteins in the membranes, scanned and calculated using Adobe Photoshop, and visualized in the form of a bar graph. Figure 1 and Table 1 show that the expression of Vimentin in the treatment group was lower compared to that of the control group, except for the concentrations of Vimentin observed on GD $17(176,18)$ and GD $18(163,83)$, which were higher compared to the control group on GD $17(120,62)$ and GD 18 $(133,00)$. All GFAP protein levels of the treatment group were lower than those of the control group, except on GD $12(139,05)$, when it was higher compared to that of the control group $(114,40)$ (Table 2).

\section{Discussion}

Brain development involves various processes, including epithelial cell proliferation and migration of precursor neurons into appropriate places in the neural tube [12]. The interaction of neurons and glial cells plays a role in the migration process, where the extracellular matrix proteins act as mediators in the process of migration and proliferation.

Table 1 Results of densitometric measurement of Vimentin in the brain of mouse fetuses of control group and treatment.

\begin{tabular}{cccccccccc}
\hline & GD 11 & GD 12 & GD 13 & GD 14 & GD 15 & GD 16 & GD 17 & GD 18 & $\begin{array}{c}\text { Total of } \\
\text { Average }\end{array}$ \\
\hline $\begin{array}{c}\text { Average } \\
\text { Vim } \\
\text { control }\end{array}$ & 141.68 & 151.80 & 135.03 & 151.55 & 155.32 & 138.82 & 120.62 & 133.00 & 140.98 \\
\hline $\begin{array}{c}\text { Average } \\
\text { Vim } \\
\text { treatment }\end{array}$ & $116.52^{*}$ & $131.60^{*}$ & $117.74^{*}$ & $122.81^{*}$ & $108.69^{*}$ & $116.84^{*}$ & $176.18^{*}$ & $163.83^{*}$ & $131.78^{*}$ \\
\hline Difference & 25.16 & 20.20 & 17.29 & 28.74 & 46.63 & 21.98 & 55.56 & 30.83 & 30.80 \\
\hline $\begin{array}{c}\% \\
\text { difference }\end{array}$ & 17.76 & 13.31 & 12.81 & 18.96 & 30.02 & 15.83 & 46.06 & 23.18 & 22.24 \\
\hline $\begin{array}{c}\text { SD Vim } \\
\text { control }\end{array}$ & 0.34 & 0.53 & 0.61 & 0.36 & 0.78 & 0.45 & 0.54 & 0.50 & 0.51 \\
\hline $\begin{array}{c}\text { SD Vim } \\
\text { treatment }\end{array}$ & 0.48 & 0.21 & 0.41 & 0.62 & 0.26 & 0.70 & 0.35 & 0.56 & 0.45 \\
\hline & $*$ Significant at P< 0,05 than control. & & & & & &
\end{tabular}


In this research, the densitometry measurements showed that the absorption of Vimentin protein expression in the brains of the mouse fetuses of the treatment group was higher than that of the control group, except on GD 17 and GD 18 (Figure 1). Besides that, the levels of absorption of GFAP expression of the treatment groups were lower than those of the control group, except on GD 12 (Figure 1).

Table 2 Results of densitometric measurement of GFAP in the brain of mouse fetuses of control group and treatmenty group.

\begin{tabular}{|c|c|c|c|c|c|c|c|c|c|}
\hline & GD 11 & GD 12 & GD 13 & GD 14 & GD 15 & GD 16 & GD 17 & GD 18 & $\begin{array}{l}\text { Total of } \\
\text { Average }\end{array}$ \\
\hline $\begin{array}{c}\text { Average } \\
\text { GFAP } \\
\text { control }\end{array}$ & 130.50 & 114.40 & 142.51 & 133.50 & 142.67 & 128.17 & 113.33 & 95.14 & 125.03 \\
\hline $\begin{array}{c}\text { Average } \\
\text { GFAP } \\
\text { treatment }\end{array}$ & $119.73 *$ & $139.05^{*}$ & $107.56 *$ & $168.58^{*}$ & $115.77 *$ & $116.01 *$ & $103.84^{*}$ & $91.80 *$ & $120.29 *$ \\
\hline difference & 10.77 & 24.65 & 34.95 & 35.08 & 26.90 & 12.16 & 9.49 & 3.34 & 19.67 \\
\hline $\begin{array}{c}\% \\
\text { difference }\end{array}$ & 8.25 & 21.55 & 24.52 & 26.28 & 18.85 & 9.49 & 8.37 & 3.51 & 15.10 \\
\hline $\begin{array}{c}\text { SD } \\
\text { GFAP } \\
\text { control } \\
\end{array}$ & 0.79 & 0.45 & 0.28 & 0.28 & 0.27 & 0.79 & 0.68 & 0.30 & 3.84 \\
\hline $\begin{array}{c}\mathrm{SD} \\
\text { GFAP } \\
\text { treatment }\end{array}$ & 0.55 & 1.65 & 0.30 & 0.32 & 0.53 & 0.71 & 0.87 & 0.95 & 0.76 \\
\hline
\end{tabular}

* Significant at $\mathrm{P}<0,05$ than control

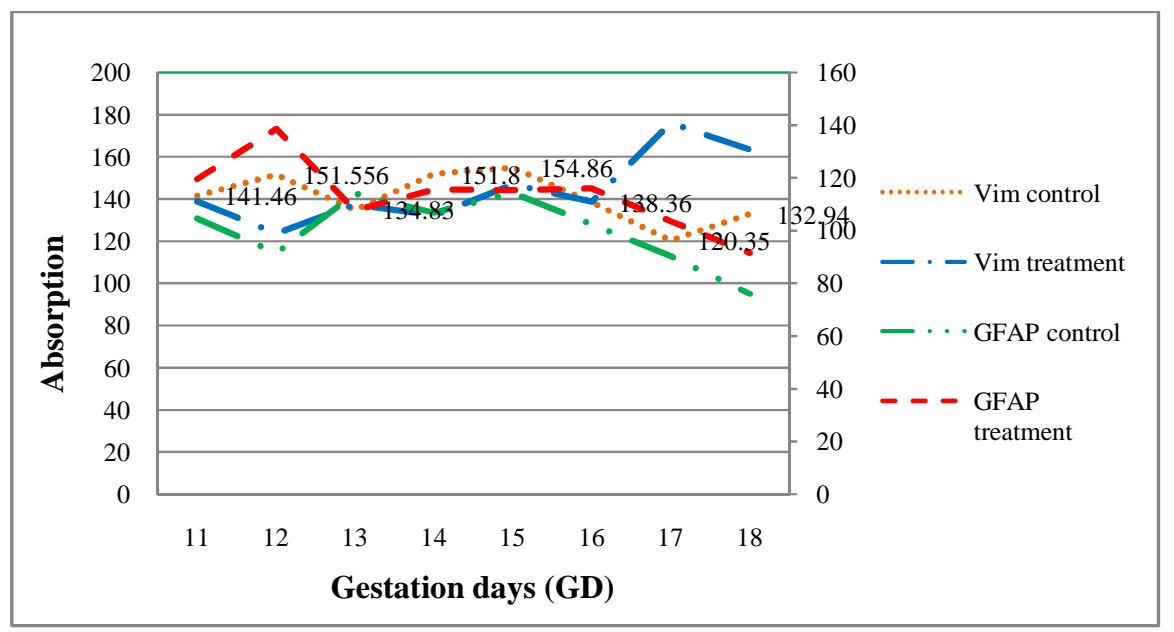

Figure 1 Graph of Vimentin and GFAP levels for control group and treatment group of mouse fetus brain, from GD 11 to GD 18 . 
Comparison between the absorption levels of Vimentin and GFAP expression in the control group reveals that the absorption level of the Vimentin protein was higher than that of GFAP. This also occurred in the treatment group. These data are supported by previous research [17], where it is observed that 2-ME caused an increase in the gene expression of Vimentin on GD 12. This means that in a normal state, the gene expression of Vimentin has decreased on GD 12 and the Vimentin gene will be expressed into Vimentin proteins. Administration of 2ME causes an increase in the expression of Vimentin gens [18], but in the present research, expression of the Vimentin protein was low. This means that interference occurs at the stage of protein translation, because the proteins have not been fully translated. This is evidenced by the low level of absorption of protein expression of Vimentin in the treatment group, while the level of absorption of GFAP expression in the fetal brain of the treatment group on GD 12 is high (Figure 1). Another reason is that Vimentin and GFAP proteins are both secreted by astrocyte cells. Astrocytes are responsive to toxic substances entering the body, making the cells secrete GFAP, which is necessary as a signal of cellular damage. Astrocytes are glial cells, appearing in the early development of the brain, and act to guide the growth of nerve cells.

It is concluded that 2-ME inhibits protein translation, resulting in a decrease in Vimentin protein levels at GD-12, except on GD 17 and GD 18. This is based on the assumption that the period from GD 11 to GD 16 is a period of recovery in which Vimentin is required to repair brain tissue through the migration of cells into the damaged cells [23]. Other reasons, the high expression of vimentin protein at GD-17 and GD-18 are a proinflammatory signaling pathway that is associated with "wound healing", so that vimentin protein also is secreted by cells of macrophage [24]. Vimentin proteins secreted by macrophage cells are used only in wound healing process. Therefore after GD 16, perhaps the recovery process and corticogenesis are over, so although on GD-17 and GD18 , all the neuroblast cells undergo a process of proliferation, and express Vimentin protein at a high level. But it is not enough to improve the process of corticogenesis.

The densitometry results show that the levels of GFAP for the treatment group from GD 11 to GD 18 are lower than those of the control group, except at GD 12. Presumably, GD 12 is the point where the recovery process starts. This is based on the assumption that astroglial cells are responsive to the toxic substance 2-ME, which causes tissue damage. As a response, astroglial cells are progressively transformed into reactive astrocytes. Changes in reactive astrocytes may alter gene expression and cause cellular changes [25], which ultimately alter the protein translation process. Other studies have shown that cells that contain activated astrocytes secrete neurotoxic substances and display an increasing level of expression of GFAP [25]. Therefore, the high of levels 
GFAP protein in the treatment group on GD 12 were caused by 2-ME. After this period, the expression of GFAP became lower again. This is associated with the expression of Vimentin. After the recovery process, the cells undergo redifferentiation or start proliferating again. In the cells undergoing proliferation, Vimentin will be expressed; Vimentin protein expression levels in the treatment group increased on GD 17 and GD 18.

High or low levels of GFAP expression are very dependent on the level of tissue damage. Once activated, the glial cells affect a series of changes in the protein expression of the astroglial cells. This means that if there is a change in GFAP expression on GD 12, it also changes Vimentin protein expression on GD 12. An increased GFAP expression is associated with pathological conditions of the central nervous system [13]. Increased expression of GFAP is aimed at maintaining homeostasic conditions. It can also change the expression of Vimentin, aiding in the survival of nerve cells. Therefore, the Vimentin protein also plays a role in the recovery process and its expression is closely related to that of the GFAP protein.

Hence, it can be concluded that changes in the expression of Vimentin are more due to the 2-ME compound. Although the cells proliferate again after GD 16, this is not enough to repair the damage that has occurred. The cells will increase in number, but a developmental disorder or failure in the placement position of a cell can not be repaired. Therefore, abnormal brain formation may occur in the treatment group.

\section{Conclusion}

We suspect that 2-ME inhibits translation of Vimentin protein at GD-12 and otherwise increase the level of GFAP protein expression as a cellular response to toxic materials. This response causes cell proliferation, which is characterized by increased levels of absorption of Vimentin protein on GD 17 and GD 18, which was higher than in the control group. It can be concluded that the Vimentin protein is essential for the development of the brain, especially to stimulate cell proliferation.

\section{Acknowledgements}

We thank Prof. Yukio Hattori Ph.D. and Prof. Yasuhiro Yamashiro, Ph.D. from Yamaguchi University, Japan. This research was performed with support from a Competitive Research Grant of DIKTI Indonesia 2011 in collaboration with Yamaguchi University, Japan. 


\section{References}

[1] Dugard, P.H., Walker, M., Mawdsley, S.J. \& Scott, R.C., Absorption of Some Glycol Ethers through Human Skin In Vitro, Environ. Health Perspect., 57, pp. 193-197, 1984.

[2] Scott, W.J., Fradkin, R., Wittfoht, W. \& Nau, H., Teratologic Potential of 2-Metoxyethanol and Transplacental Distribution of its Metabolite, 2Methoxyacetic Acid, in Non-Human Primates, Teratology, 39, pp. 363373, 1989.

[3] Brown, N.A., Holt, D. \& Webb, M., The Teratogenicity of Methoxyacetic Acid in the Rat, Toxicol. Lett., 22, pp. 93-10, 1984.

[4] Moslen, M.T., Kaphalia, L., Balasubramanian, H., Yin, Y.M. \& William, W.A., Species Differences in Testicular and Hepatic Biotransformation of 2-Methoxyethanol, Toxicol., 96, pp. 217-224, 1995.

[5] Feuston M.H., Kerstetter S.L. \& Wilson P.D., Teratogenicity of 2Methoxyethanol Applied As A Single Dermal Dose to Rats, Fundam. Appl. Toxicol., 15, pp. 448-456, 1990.

[6] Darmanto, W., Efek 2-Methoxyethanol terhadap Pembentukan Somite dan Kelainan Rangka Aksial pada Mencit, Proceeding Temu Ilmiah VII, Hiroshima, Japan, pp. 19-22, 1998.

[7] Prihiyantoro, E., Darmanto, W., Pidada, I.B. \& Soepriandono, H., Gangguan Migrasi dan Perkembangan Sel Saraf Pada Cerebrum dan Cerebelum Mencit Akibat Induksi 2-Methoxyethanol; sebagai Model Mekanisme Kelainan Otak, Laporan Penelitian Hibah Bersaing X/3, 2004.

[8] Gilbert, S.F., Development Biology, $6^{\text {th }}$ edition, Sinauer Associates, Inc. 2000.

[9] Bruce, A., Johnson, A., Lewis, J., Raff, M., Robert, K. \& Walter, P., Molecular Biology of The Cell, $5^{\text {th }}$ edition, Printed in the United States of America, 2008.

[10] Darmanto, W., Inouye, M., Takagishi, Y., Ogawa, M., Mikoshiba, K. \& Murata, Y., Derangement of Purkinje Cells in The Rat Cerebellum Following Prenatal Exposure to X-Irradiation: Decreased Reelin Level is Possible Cause, Journal Neuropathology and Experimental Neurology, 59(3), pp. 251-262, 2000.

[11] Dutta, S., Ghosh, S., Gangopadhyay, P.K. \& Usha, R., Role of Reelin in The Development of Cerebral Cortex, Journal of Cell and Tissue Research, 5(2), pp. 497-505, 2005.

[12] Götz, B., Scholze, A., Clement, A., Joester, A., Schutte., K.,Wigger, F., Frank, R., Spiess, E., Ekblom, P. \& Faissner, A., Tenascin-C Contain distinct Adhesive and Neurite Outgrowth Promoting Site for Neuron, The Journal of Cell Biology, 132(4), pp. 681-699, 1996. 
[13] Duprey, P. \& Paulin, D., Review: What Can be Learned From Intermediet Filament Gene Regulation in The Mouse Embryo, Int. J. Dev. Biol, 39(3), pp. 443-457, 1995.

[14] Liu, Q., Xieb, F., Siedlak, S.L., Nunomurac, A., Hondaa, K., Moreiraa, P.I., Zhua, X., Smitha, M.A. \& Perrya, G., Neurofilament Proteins in Neurodegenerative Diseases, Cell. Mol. Life Sci., 61(24), pp. 3057-3075, 2004.

[15] Kolkova, K., Biosynthesis of NCAM, Review Article, Neurochem. Res., 2008.

[16] Helfand, B.T., Mendez, M.G., Murthy, S.N., Shumaker, D.K., Grin, B., Mahammad, S., Aebi, U., Wedig, T., Wu, Y.I., Hahn, K.M., Inagaki, M., Herrmann, H. \& Goldman, R.D., Vimentin Organization Modulates The Formation of Lamellipodia, Molecular Biology of the Cell, 22(8), pp. 1274-1289, 2011.

[17] Irnidayanti, Y., Darmanto, W. \& Abadi, A., The Expression of Gen Extracellular Matrix and Cell Adhesion Molecule of Brain Embryo Mice at GD 10 By real time RT-PCR, World Academy Science Engineering And Technology Journal (WASET), 58, pp. 705-708, 2011.

[18] Irnidayanti, Y., Darmanto, W. \& Abadi, A., Expression of Level Gen mRNA of Ekstraseluler Protein Embrio Brain Mice Black-6 at GD 12 Caused by Induced 2-Methoxyethanol: Analysis by Real Time RT-PCR, Berkala Penelitian Hayati, Unair, 15(2), pp. 171-179, 2010.

[19] Oudega, M. \& Marani, E., Expression of Vimentin and Glial Fibrillary Acidic Protein in The Developing Rat Spinal Cord: An ImmuneCytochemical Study of The Spinal Cord Glial System, J. Anat., 179, pp. 97-114, 1991.

[20] Rugh, R., The Mouse: Its Reproduction and Development, Burgess Publishing Company, Minneapolis, 1968.

[21] Wilhelmsson, U., Li, Z., Pekna, M., Berthold, C.H., Blom, S., Eliasson, C., Renner, O., Bushong, E., Ellisman, M., Morgan, T.E. \& Pekny, M., Absence of Glial Fibrillary Acidic Protein and Vimentin Prevents Hypertrophy of Astrocytic Processes and Improves Post traumatic Regeneration, J. Neurosci. Search, 24 (21), pp. 5016-5021, 2004.

[22] Galou, M., Colluci-Guyon, E., Ensergueix, D., Ridet, J.L., Gimenez, Y.R.M., Privat, A., Babinet, C. \& Dupouey, P., Disrupted Glial Fibrillary Acidic Protein Netwoek in Astrocytes from Vimentin Knockout Mice, J. Cell. Bio, 133(4), p. 853-863,1996.

[23] Moon, C., Ahn, M., Kim, S., Jin, J-K., Sim, K-B., Kim, H-M., Lee, M. Y., Shin, T., Temporal Patterns of The Embryonic Intermediate Filaments Nestin and Vimentin Expression in The Cerebral Cortex of Adult Rats After Cryoinjury, Brain Res, 1028(2), pp. 238-242, 2004. 
[24] Vaknin, N.M., Punturieri, A., Sitwala, K. \& Markovitz, D.M., Vimenitn is Secreted by Activated Macrophage, Nature Cell Biology, 5, pp. 59-63, 2003.

[25] Brahmachari, S., Fung, Y.K. \& Pahan, K., Induction of Glial Fibrillary Acidic Protein Expression in Astrocytes by Nitric Oxide, J. Neurosci., 26(18), pp. 4930-4939, 2006. 